\title{
Kesabaran dan Kesehatan Mental dalam Bimbingan Konseling Islam
}

\author{
Najamuddin \\ Fakultas Dakwah dan Komunikasi UIN Mataram \\ najam_najamudin@ymail.com
}

\begin{abstract}
Every human must be able to balance between intellectual intelligence and emotional intelligence. Emotional intelligence is measured of the ability to control the emotion and to refrain. In Islam, the ability of controlling the emotion and patience are mentioned the patience. Patience demands patience in the face of something difficult, heavy, and bitter, to be accepted and faced with full responsibility. Nowadays, patience is understood by many people to aim toward passive nature of patience, in meaning of resigning does not do anything when faced with problems. While in Islamic view, patience means to be strong, to stand firm, or not to despair when facing obstacles, and to keep trying maximally. In addition, someone's mental health is the ability to adjust to the circumstances encountered, can utilize all the potential and talent as much as possible and bring to the harmony in life must also be considered. Meanwhile, Islamic counseling is a process of providing assistance to individuals to realize again its existence as a creature of God who should live in harmony with the provisions and instructions of God so as to achieve happiness in the world and in the afterlife. Urgency of preaching with the concept of patience that preaching can help clarify and illuminate the mad'u about how patience is consistent with the Qur'an and hadist. The existing of preaching is so that the mistake in understanding the patience can be reduced. The problematic society today is not only about
\end{abstract}


material issues, but also about psychological problems. So, between patience, mental health and counseling Islam must be framed in preaching.

Keywords: Patience, Mental Health, leading of Islam counseling, Preaching.

\section{Pendahuluan}

Setiap manusia dalam kehidupannya menghendaki dapat meraih sukses, untuk meraih sukses tidak cukup hanya mengandalkan kecerdasan intelektual. Dengan kata lain, dibutuhkan pula kecerdasan lain yang dapat menopang keberhasilannya, yaitu kecerdasan emosional. Kecerdasan emosional diukur dari kemampuan mengendalikan emosi dan menahan diri. Dalam Islam kemampuan mengendalikan emosi dan menahan diri disebut sabar. Orang yang paling sabar adalah orang yang paling tinggi kecerdasan emosionalnya. Ia biasanya tabah menghadapi kesulitan. Ketika belajar biasanya orang ini tekun. Ia biasanya berhasil mengatasi berbagai gangguan dan tidak memperturutkan emosinya, ia dapat mengendalikan emosinya. ${ }^{1}$ Kesabaran mengajari manusia ketekunan dalam bekerja serta mengerahkan kemampuan untuk merealisasikan tujuan-tujuan amaliah dan ilmiahnya. Sesungguhnya sebagian besar tujuan hidup manusia, baik di bidang kehidupan praksis, misalnya sosial, ekonomi, dan politik, maupun dalam bidang penelitian ilmiah, membutuhkan banyak waktu dan banyak kesungguhan. Oleh sebab itu, ketekunan dalam mencurahkan kesungguhan serta kesabaran dalam menghadapi kesulitan pekerjaan dan penelitian merupakan karakter penting untuk meraih kesuksesan dan mewujudkan tujuan-tujuan luhur. ${ }^{2}$ Kesabaran menuntut ketabahan dalam menghadapi sesuatu yang sulit, berat, dan pahit, yang harus diterima dan dihadapi dengan penuh

1 Musthafa Fahmi, Kesehatan Jiwa dalam Keluarga, Sekolah, dan Masyarakat (Jakarta: Bulan Bintang, 1977), 166.

2 Muhammad Ustman Najati, Psikologi dalam al-Qur'an: Terapi Qur'ani dalam Penyembuhan Gangguan Kejiwaan (Bandung: CV Pustaka Setia, 2005), 467, 471. 
tanggung jawab. Berdasarkan kesimpulan tersebut, Shihab merumuskan pengertian sabar sebagai "menahan diri atau membatasi jiwa dari keinginannya demi mencapai sesuatu yang baik atau lebih baik (luhur)". ${ }^{3}$ Menurut al-Jauziyyah, ${ }^{4}$ sabar berarti menahan diri dari rasa gelisah, cemas, dan amarah; menahan lidah dari keluh kesah; menahan anggota tubuh dari kekacauan. Menurut Mubarok, ${ }^{5}$ sabar adalah tabah hati tanpa mengeluh dalam menghadapi godaan dan rintangan dalam jangka waktu tertentu dalam rangka mencapai tujuan.

Dengan demikian, sabar adalah bertahan diri untuk menjalankan berbagai ketaatan, menjauhi larangan, dan menghadapi berbagai ujian dengan rela dan pasrah. Ash-Shabur (Yang Maha Sabar) juga merupakan salah satu asma'ul husna Allah Swt., yakni yang tak tergesa-gesa melakukan tindakan sebelum waktunya. Dalam agama, sabar merupakan satu di antara stasiun-stasiun (maqamat) agama, dan satu anak tangga dari tangga seorang salik dalam mendekatkan diri kepada Allah. Struktur maqamat (kedudukan) agama terdiri dari (1) pengetahuan (ma'arif) yang dapat dimisalkan sebagai pohon; (2) sikap (ahwal) yang dapat dimisalkan sebagai cabangnya; dan (3) perbuatan (amal) yang dapat dimisalkan sebagai buahnya. Seseorang bisa bersabar jika dalam dirinya sudah terstruktur maqamat itu. Sabar bisa bersifat fisik, bisa juga bersifat psikis. Sabar bermakna kemampuan mengendalikan emosi, maka nama sabar berbeda-beda tergantung objeknya. ${ }^{6}$

Terlepas dari beragam pandangan tentang maqam shabr, pada dasarnya kesabaran adalah wujud dari konsistensi diri seseorang untuk memegang prinsip yang telah dipegangi sebelumnya. ${ }^{7}$ Atas dasar itu,

${ }^{3}$ M. Quraish Shihab, Wawasan al-Qur'an: Tafsir Maudhu'i atas Pelbagai Persoalan Umat (Bandung: Mizan, 1996), 165-166.

4 Ibn Qayyim al-Jauziyah, Mukhtashar Zâdul Mảad (Jakarta: Pustaka Azzam, 2004), 206.

5 Achmad Mubarok, Solusi Krisis Keruhanian Manusia Modern: Jiwa dalam al-Qur'an (Jakarta: Paramadina, 2000), 73.

6 Saiful Akhyar Lubis, Konseling Islami (Yogyakarta: eLSAQ Press, 2007), 342.

7 Hasyim Muhammad, Dialog antara Tasawuf dan Psikologi (Yogyakarta: Anggota IKAPI, 2002), 44. 
maka al-Qur'an mengajak kaum Muslimin agar berhias diri dengan kesabaran sebab kesabaran mempunyai faedah yang besar dalam membina jiwa, memantapkan kepribadian, meningkatkan kekuatan manusia dalam menahan penderitaan, memperbaharui kekuatan manusia dalam menghadapi berbagai problem hidup, beban hidup, musibah, dan bencana, serta menggerakkan kesanggupannya untuk terus-menerus berjihad dalam rangka meninggikan kalimah Allah Swt.

Sebagaimana telah dinyatakan sebelumnya, orang yang sabar akan mampu menerima segala macam cobaan dan musibah. Berbagai musibah dan malapetaka yang melanda Indonesia telah dirasakan masyarakat. Bagi orang yang sabar maka ia rela menerima kenyataan pahit, sementara yang menolak dan atau tidak sabar, ia gelisah dan protes dengan nasibnya yang kurang baik. Realita fenomena di masyarakat terjadi suatu kesenjangan antara teori yang mengharuskan ikhtiar maksimal dengan sabar diri sepenuhnya tanpa usaha. Dengan kata lain, kenyataan menunjukkan bahwa persepsi yang berkembang di sebagian masyarakat, sabar dipahami sebagai bentuk pasrah diri pada Allah yang tanpa ikhtiar. Persepsi yang keliru ini mengakibatkan umat Islam berada dalam kemunduran dan tidak mampu bersaing dengan dinamika zaman. Kenyataan ini dapat dijumpai dalam kehidupan sehari-hari.

Keterangan di atas sejalan dengan pernyataan Yafie, ${ }^{8}$ sekarang ini sabar dipahami oleh banyak orang hanya menjurus kepada sifat sabar yang pasif, dalam arti pasrah tidak berbuat apa-apa tatkala menghadapi persoalan. Padahal, dalam ajaran Islam menganjurkan berbuat sesuatu untuk kelangsungan kehidupannya, maka sabar bisa berarti tegar, berdiri kokoh, atau tidak berputus asa ketika menghadapi rintangan, dan tetap berusaha secara maksimal. Artinya, ayat-ayat al-Qur'an tidak dapat dilihat secara sendiri-sendiri dan terjebak dalam maknanya yang tersurat saja, tetapi perlu dilihat secara lebih menyeluruh dan ditafsirkan secara kontekstual. Di sinilah perlunya ada pengkajian secara mendalam dan kontinyu tentang tema sabar.

\footnotetext{
8 Ali Yafie, “Mata Rantai yang Hilang,” Pesantren, No. 2, Vol. II (1985), 154-155.
} 
Menurut ash-Shiddieqy, ${ }^{9}$ sabar ialah tahan menderita atas yang tidak disenangi dengan rela dan menyerahkan diri kepada Allah. Dengan demikian, sabar yang benar ialah sabar yang menyerahkan diri kepada Allah dan menerima ketetapan-Nya dengan dada yang lapang, bukan karena terpaksa. Menurut Nasution, ${ }^{10}$ sabar itu membentuk jiwa manusia menjadi kuat dan teguh tatkala menghadapi bencana (musibah). Jiwanya tidak bergoncang, tidak gelisah, tidak panik, tidak hilang sikap keseimbangannya. Hatinya tabah menghadapi bencana itu, tidak berubah pendiriannya. Tak ubahnya laksana batu karang di tengah-tengah lautan yang tidak bergeser sedikitpun tatkala dipukul ombak yang bergulunggulung.

Dalam masyarakat bergulir sebuah anggapan bahwa sabar yang sesungguhnya adalah kepasrahan seorang hamba terhadap Allah Swt. tanpa perlu usaha. Banyak orang yang diam bertopang dagu. Mereka beranggapan bahwa jika sudah menjadi rezekinya, maka ia tidak akan ke mana-mana. Sebaliknya, apabila bukan rezekinya maka dikejar pun akan lari dan menjauh. Kekeliruan persepsi dan interpretasi seperti ini merupakan salah satu fenomena ketidakmampuan manusia itu dalam berkompetisi di tengah-tengah masyarakat yang makin kompleks. Bertitik tolak dari fenomena tersebut, sabar mempunyai kaitan yang erat dengan dakwah. Berbicara sabar tidak dapat dipisahkan dengan dakwah. Masih banyak orang yang sabar secara berlebihan, ia terlalu memasrahkan dirinya dalam berbagai hal namun tanpa ikhtiar atau usaha sama sekali. Sabar bukan hanya berserah diri melainkan ia perlu usaha dahulu secara maksimal baru kemudian sabar. Kenyataan menunjukkan bahwa masih terdapat kesenjangan antara teori sabar yang mengharuskan usaha atau ikhtiar dengan realita yang ada di masyarakat yaitu sabar tanpa usaha.

Urgensi dakwah dengan konsep sabar, yaitu dakwah dapat membantu memperjelas dan memberi penerangan pada mad'u tentang bagaimana

9 M. Hamdani Bakran adz-Dzaky, Konseling dan Psikoterapi Islam: Penerapan Metode Sufistik (Yogyakarta: Fajar Pustaka Baru, 2002), 13.

${ }^{10}$ Harun Nasution, Islam Ditinjau dari Berbagai Aspeknya (Jakarta: UI Press, 1985), 188. 
sabar yang sesuai dengan al-Qur'an dan Hadis. Dengan adanya dakwah, maka kekeliruan dalam memaknai sabar dapat dikurangi. Problematika masyarakat sekarang ini bukan saja menyangkut masalah materi, tetapi menyangkut masalah-masalah psikologis. Hal ini disebabkan oleh semakin modern suatu masyarakat maka semakin bertambah intensitas dan eksistensi berbagai disorganisasi dan disintegrasi sosial masyarakat. ${ }^{11}$ Kondisi ini telah mengakibatkan makin keringnya ruhani manusia dari agama. Itulah sebabnya, Umary merumuskan bahwa dakwah adalah mengajak orang kepada kebenaran, mengerjakan perintah, menjauhi larangan agar memperoleh kebahagiaan di masa sekarang dan yang akan datang. ${ }^{12}$ Sejalan dengan itu, Sanusi menyatakan, dakwah adalah usaha-usaha perbaikan dan pembangunan masyarakat, memperbaiki kerusakan-kerusakan, melenyapkan kebatilan, kemaksiatan, dan ketidakwajaran dalam masyarakat. ${ }^{13}$ Dengan demikian, dakwah berarti memperjuangkan yang ma'ruf atas yang munkar, memenangkan yang hak atas yang batil. Esensi dakwah adalah terletak pada ajakan, dorongan (motivasi), rangsangan serta bimbingan terhadap orang lain untuk menerima ajaran agama dengan penuh kesadaran demi untuk keuntungan pribadinya sendiri, bukan untuk kepentingan juru dakwah. ${ }^{14}$

Dengan dakwah maka kekeliruan persepsi dapat diluruskan, dalam hal ini persepsi tentang sabar. Atas dasar itu, untuk mewujudkan dakwah tentang sabar yang benar maka perlu adanya pemahaman konsep sabar yang jelas dan sesuai dengan al-Qur'an dan Hadis. Dakwah tidak ditujukan pada mad'u secara individual melainkan terdiri dari banyak orang, sedangkan bimbingan Islami bisa dilakukan dalam bentuk individual. Maka dalam konteksnya dengan klien yang tidak sabar dalam menghadapi kehidupan terutama ketika ditimpa musibah, keluhan klien tersebut

${ }^{11}$ Abdul Aziz Ahyadi, Psikologi Agama, Kepribadian Muslim Pancasila (Bandung: Sinar Baru al-Gesindo, 1995), 177.

12 Barmawie Umary, Azas-Azas Ilmu Dakwah (Semarang: CV. Ramadhani, 1980), 52.

${ }^{13}$ Shalahuddin Sanusi, Pembahasan Sekitar Prinsip-Prinsip Dakwah Islam (Semarang: CV. Ramadhani, t.t.), 11.

${ }^{14}$ Amrullah Ahmad, Dakwah Islam dan Perubahan Sosial (Yogyakarta: Primaduta, 1983), 6 . 
dapat diatasi oleh konselor. Dari sini tampak hubungan yang saling melengkapi antara dakwah dengan bimbingan Islami.

\section{Konsep Sabar}

Sabar (ash-shabru) menurut bahasa adalah menahan diri dari keluh kesah. Ada pula ash-shibru dengan meng-kasrah-kan shad artinya obat yang pahit, yakni sari pepohonan yang pahit. Menyabarkannya berarti menyuruhnya sabar. Bulan sabar, artinya bulan puasa. Ada yang berpendapat, sabar adalah keras dan kuat. Ash-Shibru tertuju pada obat yang terkenal sangat pahit dan sangat tak enak. Al-ushmu'i mengatakan, "Jika seorang lelaki menghadapi kesulitan secara bulat." Artinya, ia menghadapi kesulitan itu secara sabar. Ada pula ash-shubru dengan men-dhamah-kan shad, tertuju pada tanah yang subur karena kerasnya. ${ }^{15}$ Ada pula yang berpendapat, sabar itu diambil dari kata mengumpulkan, memeluk, atau merangkul sebab orang yang sabar itu yang merangkul atau memeluk dirinya dari keluh-kesah. Ada pula kata shabrah yang tertuju pada makanan. Pada dasarnya, dalam sabar itu ada tiga arti, menahan, keras, mengumpulkan, atau merangkul, sedang lawan sabar adalah keluh-kesah. ${ }^{16}$ Dari arti-arti yang dikemukakan di atas, dapat disimpulkan bahwa kesabaran menuntut ketabahan dalam menghadapi sesuatu yang sulit, berat, dan pahit, yang harus diterima dan dihadapi dengan penuh tanggung jawab. M. Quraish Shihab merumuskan pengertian sabar sebagai menahan diri atau membatasi jiwa dari keinginannya demi mencapai sesuatu yang baik atau lebih baik (luhur). ${ }^{17}$ Ibn Qayyim al-Jauziyyah menjelaskan, sabar artinya menahan diri dari rasa gelisah, cemas dan amarah; menahan lidah dari keluh kesah; menahan anggota tubuh dari kekacauan. ${ }^{18}$ Menurut Achmad Mubarok, sabar adalah tabah

\footnotetext{
${ }^{15}$ Lubis, Konseling Islami, 342.

${ }^{16}$ Ibid.

${ }^{17}$ Shihab, Wawasan al-Qur'an, 165-166.

${ }^{18}$ Ibn Qayyim al-Jauziyah, Madarijus Salikin, Pendakian Menuju Allah: Penjabaran Konkret: Iyyaka Na'budu wa Iyyaka Nasta'in. terj. Kathur Suhardi (Jakarta: Pustaka al-Kautsar, 2003), 206.
} 
hati tanpa mengeluh dalam menghadapi godaan dan rintangan dalam jangka waktu tertentu dalam rangka mencapai tujuan. ${ }^{19}$ Menurut para ulama, beberapa definisi sabar antara lain:

a. Diam terhadap musibah.

b. Berteguh hati atas aturan-aturan al-Qur'an dan as-Sunnah.

c. Tak pernah mengadu.

d. Tidak ada perbedaan antara sedang nikmat dan sedang diuji meskipun keduanya mengandung bahaya. ${ }^{20}$

Dengan demikian sabar adalah bertahan diri untuk menjalankan berbagai ketaatan, menjauhi larangan dan menghadapi berbagai ujian dengan rela dan pasrah. Ash-Shabur (Yang Maha Sabar) juga merupakan salah satu asma'ul husna Allah Swt., yakni yang tak tergesa-gesa melakukan tindakan sebelum waktunya. ${ }^{21}$

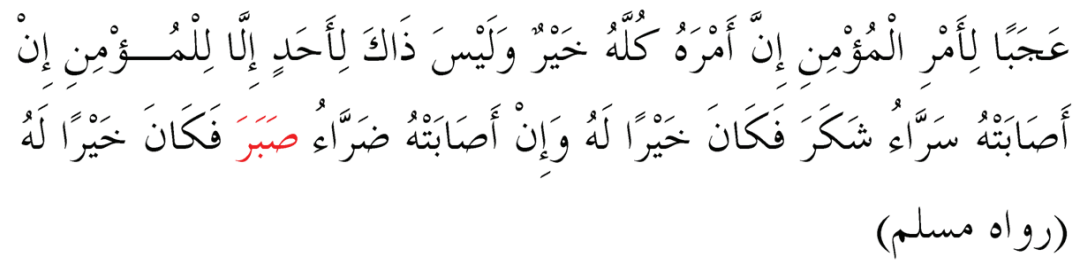

Menakjubkan urusan orang yang beriman itu! Urusannya seluruhnya baik baginya, dan hal itu tidak dimiliki oleh seorang pun kecuali orang yang beriman, jika dia mendapatkan kegembiraan, maka ia bersyukur, dan rasa syukur itu lebih baik baginya, jika ia mendapatkan musibah, maka ia bersabar, dan bersabar itu lebih baik baginya (HR. Muslim).

Dari Abu Malik asy-Asy’ari, ia berkata bahwa Rasulullah Saw. bersabda:

\footnotetext{
${ }^{19}$ Mubarok, Solusi Krisis, 73.

${ }^{20}$ Lubis, Konseling Islami, 343.

${ }^{21}$ Ibid.
} 


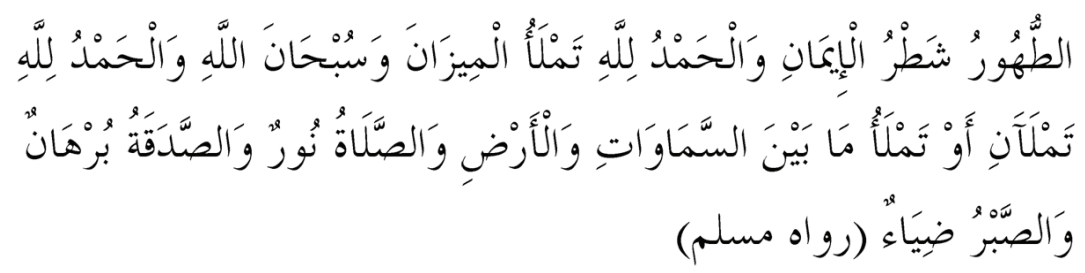

Kesucian itu sebagian dan iman, Alhamdulillah memenuhi Mizan (timbangan hari Kiamat), Subhanallah walhamdu lillah memenuhi ruang antara langit dan bumi, shalat itu cahaya, sedekah itu sebagai bukti, dan sabar itu sinar (HR. Muslim).

Dalam agama, sabar merupakan satu di antara stasiun-stasiun (maqamat) agama, dan satu anak tangga dari tangga seorang salik dalam mendekatkan diri kepada Allah. Struktur maqamat agama terdiri dari (1) pengetahuan (ma'arif) yang dapat dimisalkan sebagai pohon, (2) sikap (ahwal) yang dapat dimisalkan sebagai cabangnya, dan (3) perbuatan (amal) yang dapat dimisalkan sebagai buahnya. Seseorang bisa bersabar jika dalam dirinya sudah terstruktur maqamat itu. Sabar bisa bersifat fisik, bisa juga bersifat psikis. Sabar bermakna kemampuan mengendalikan emosi, maka nama sabar berbeda-beda tergantung objeknya.

1. Ketabahan menghadapi musibah, disebut sabar, dan kebalikannya adalah gelisah (jaza') dan keluh kesah (hala').

2. Kesabaran menghadapi godaan hidup nikmat disebut, mampu menahan diri (dlobith an-nafs), kebalikannya adalah tidak tahanan (bathar).

3. Kesabaran dalam peperangan disebut pemberani, dan sebaliknya disebut pengecut.

4. Kesabaran dalam menahan marah disebut santun (hilm), kebalikannya disebut pemarah (tazammur).

5. Kesabaran dalam menghadapi bencana yang mencekam disebut lapang dada, kebalikannya disebut sempit dadanya.

6. Kesabaran dalam mendengar gosip disebut mampu menyembunyikan rahasia (katum). 
7. Kesabaran terhadap kemewahan disebut $z u h u d$, kebalikannya disebut serakah, loba (al-hirsh).

8. Kesabaran dalam menerima yang sedikit disebut kaya hati (qana'ah), kebalikannya disebut tamak, rakus (syarahun).22

Terlepas dari beragam pandangan tentang maqam shabr, pada dasarnya kesabaran adalah wujud dari konsistensi diri seseorang untuk memegang prinsip yang telah dipegangi sebelumnya. ${ }^{23}$ Atas dasar itu, maka al-Quran mengajak kaum Muslimin agar berhias diri dengan kesabaran. Sebab, kesabaran mempunyai faedah yang besar dalam membina jiwa, memantapkan kepribadian, meningkatkan kekuatan manusia dalam menahan penderitaan, memperbaharui kekuatan manusia dalam menghadapi berbagai problem hidup, beban hidup, musibah, dan bencana, serta menggerakkan kesanggupannya untuk terus-menerus berjihad dalam rangka meninggikan kalimah Allah Swt.

Menurut Ibn Qayyim al-Jauziyyah, terdapat tiga macam sabar: Sabar dalam ketaatan kepada Allah, sabar dari kedurhakaan kepada Allah, dan sabar dalam ujian Allah. ${ }^{24}$ Dua macam yang pertama merupakan kesabaran yang berkaitan dengan tindakan yang dikehendaki dan yang ketiga tidak berkait dengan tindakan yang dikehendaki. Menurut Yusuf Qardawi, dalam al-Qur'an terdapat banyak aspek kesabaran yang dirangkum dalam dua hal yakni menahan diri terhadap yang disukai dan menanggung hal-hal yang tidak disukai: ${ }^{25}$

\section{Sabar terhadap Petaka Dunia}

Cobaan hidup, baik fisik maupun non fisik, akan menimpa semua orang, baik berupa lapar, haus, sakit, rasa takut, kehilangan orang-orang yang dicintai, kerugian harta benda dan lain sebagainya. Cobaan seperti

\footnotetext{
${ }^{22}$ Mubarok, Solusi Krisis, 73-74.

${ }^{23}$ Muhammad, Dialog Antara Tasawuf, 44.

${ }^{24}$ Al-Jauziyah, Mukhtashar Zâdul, 206.

${ }^{25}$ Yusuf Qardawi, al-Qur'an Menyuruh Kita Sabar, terj. Aziz Salim Basyarahil (Jakarta: Gema Insani Press, 1990), 39.
} 
itu bersifat alami, manusiawi, oleh sebab itu tidak ada seorangpun yang dapat menghindar. Yang diperlukan adalah menerimanya dengan penuh kesabaran, seraya memulangkan segala sesuatunya kepada Allah Swt. Allah berfirman dalam Q.S. al-Baqarah ([2]: 155-157) berikut.

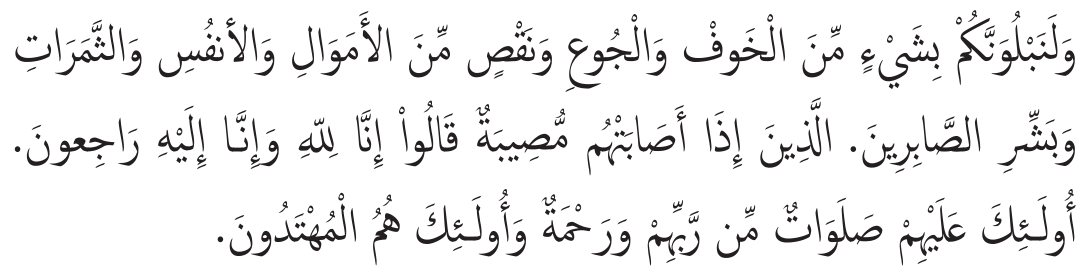

Dan sungguh akan Kami berikan cobaan kepadamu, dengan sedikit ketakutan, kelaparan, kekurangan harta, jiwa dan buahbuahan. Dan berikanlah berita gembira kepada orangorang yang sabar. Yaitu orang-orang yang apabila ditimpa. musibah, mereka mengucapkan inna lillahi wa inna ilaihi raji'un. Mereka itulah yang mendapat keberkatan yang sempurna dan rahmat dari Tuhan mereka, dan mereka itulah orang-orang yang mendapat petunjuk.

\section{Sabar terhadap Gejolak Naisu}

Hawa nafsu menginginkan segala macam kenikmatan hidup, kesenangan dan kemegahan dunia. Untuk mengendalikan segala keinginan itu diperlukan kesabaran. Jangan sampai semua kesenangan hidup dunia itu membuat seseorang lupa diri, apalagi lupa Tuhan. Al-Qur'an mengingatkan, jangan sampai harta benda dan anak-anak (di antara yang diinginkan oleh hawa nafsu manusia) menyebabkan seseorang lalai dari mengingat Allah Swt.

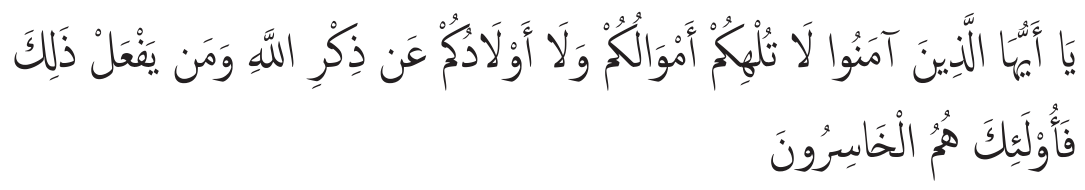

Hai orang-orang yang beriman, janganlah harta-hartamu dan anak-anakmu melalaikan kamu dari mengingat Allah. Barangsiapa yang membuat demikian, maka mereka itulah orang-orang yang rugi. (Q.S. al-Munafiqun [63]: 9) 


\section{Sabar dalam Ta'at kepada Allah SWT}

Dalam menta'ati perintah Allah, terutama dalam beribadah kepadaNya diperlukan kesabaran. Allah berfirman:

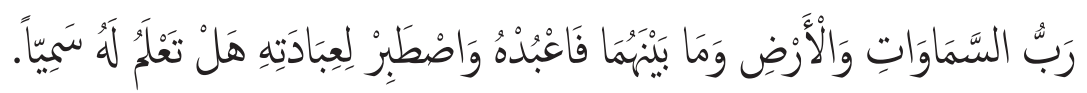

Tuhan langit dan bumi dan apa-apa yang ada di antara keduanya, maka sembahlah Dia dan berteguh hatilah dalam beribadat kepada-Nya. Apakah kamu mengetahui ada seorang yang sama dengan Dia (yang patut disembah)? (QS. Maryam [19]: 65)

Penggunaan kata ishthabir dalam ayat di atas bentuk mubalaghah dari ishbir menunjukkan bahwa dalam beribadah diperlukan kesabaran yang berlipat ganda mengingat banyaknya rintangan baik dari dalam maupun luar diri. ${ }^{26}$

\section{Sabar dalam Berdakwah}

Jalan dakwah adalah jalan panjang berliku-liku yang penuh dengan segala onak dan duri. Seseorang yang melalui jalan itu harus memiliki kesabaran. Luqman Hakim menasihati putranya supaya bersabar menerima cobaan dalam berdakwah.

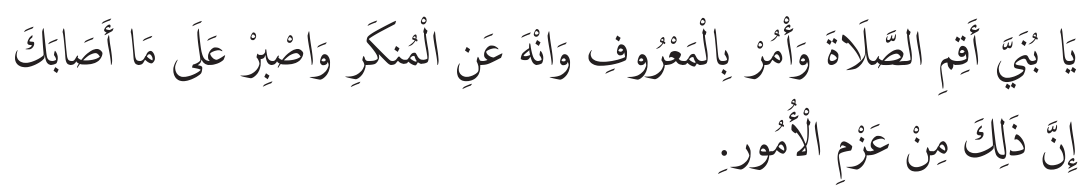

Hai anakku, dirikanlah shalat dan suruhlah (manusia) mengerjakan yang baik dan cegahlah (mereka) dari perbuatan yang mungkar dan bersabarlah terhadap apa yang menimpa kamu. Sesungguhnya yang demikian itu termasuk hal-hal yang diwajibkan (oleh Allah). (Q.S. Luqman [31]: 17)

\footnotetext{
${ }^{26}$ Yunahar Ilyas, Kuliah Akhlak (Yogyakarta: LPPI, 2004), 134.
} 


\section{Sabar dalam Perang}

Dalam peperangan sangat diperlukan kesabaran, apalagi menghadapi musuh yang lebih banyak atau lebih kuat. Dalam keadaan terdesak sekalipun, seorang prajurit Islam tidak boleh lari meninggalkan medan perang, kecuali sebagai bagian dari siasat perang (Q.S. al-Anfal [8]: 15-16). Di antara sifat-sifat orang-orang yang bertaqwa adalah sabar dalam peperangan:

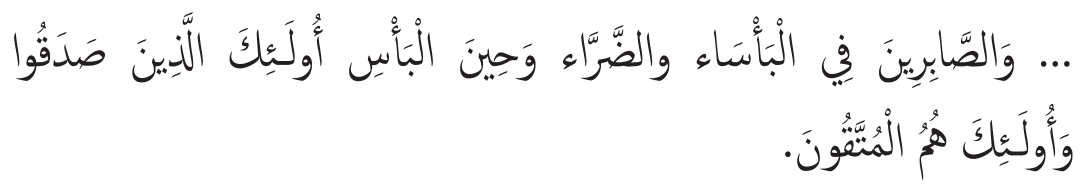

Dan orang-orang yang sabar dalam kesempitan, penderitaan dan dalam peperangan. Mereka itulah orang-orang yang benar (imannya) dan mereka itulah orang-orang yang bertakwa. (QS. alBaqarah [2]: 177)

\section{Sabar dalam Pergaulan}

Dalam pergaulan sesama manusia baik antara suami dan istri, antara orang tua dengan anak, antara tetangga dengan tetangga, antara guru dan murid, atau dalam masyarakat yang lebih luas, akan ditemui hal-hal yang tidak menyenangkan atau menyinggung perasaan. Oleh sebab itu, dalam pergaulan sehari-hari diperlukan kesabaran sehingga tidak cepat marah, atau memutuskan hubungan apabila menemui hal-hal yang tidak disukai. Kepada para suami diingatkan untuk bersabar terhadap hal-hal yang tidak dia sukai pada diri istrinya, karena boleh jadi yang dibenci itu ternyata mendatangkan banyak kebaikan. ${ }^{27}$

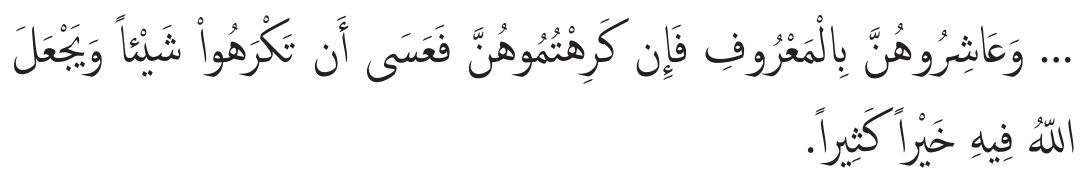

Dan bergaullah dengan mereka secara patut. Kemudian bila kamu tidak menyukai mereka, (maka bersabarlah) karena mungkin

\footnotetext{
${ }^{27}$ Ibid., 135.
} 
kamu tidak menyukai sesuatu, padahal Allah menjadikan padanya kebaikan yang banyak. (QS. an-Nisa' [4]: 19)

Adapun tingkatan orang sabar ada tiga macam, pertama, orang yang dapat menekan habis dorongan hawa nafsu hingga tidak ada perlawanan sedikitpun, dan orang itu bersabar secara konstan. Mereka adalah orang yang sudah mencapai tingkat shiddiqin. Kedua, orang yang tunduk total kepada dorongan hawa nafsunya sehingga motivasi agama sama sekali tidak dapat muncul. Mereka termasuk kategori orang-orang yang lalai (al-ghofilun). Ketiga, orang yang senantiasa dalam konflik antara dorongan hawa nafsu dengan dorongan keberagamaan. Mereka adalah orang yang mencampuradukkan kebenaran dengan kesalahan. ${ }^{28}$

Secara psikologis, tingkatan orang sabar dapat dibagi menjadi tiga, yaitu, pertama, orang yang sanggup meninggalkan dorongan syahwat. Mereka termasuk kategori orang-orang yang bertaubat (at-taibin). Kedua, orang yang ridla (senang atau puas) menerima apapun yang ia terima dari Tuhan, mereka termasuk kategori zahid. Ketiga, orang yang mencintai apapun yang diperbuat Tuhan untuk dirinya, mereka termasuk kategori shidddiqin. ${ }^{29}$ Dalam sejarah kehidupan para Nabi-Nabi dan Rasul-Rasul banyak dijumpai contoh-contoh kesabaran di segala bidang, di antaranya kesabaran Nabi Ayub dalam menghadapi musibah. Nabi Ayub adalah seorang Nabi yang kaya, mempunyai harta yang cukup, anak yang baikbaik, sahabat yang banyak dan lain-lain. Tapi, semua nikmat-duniawi itu tidaklah sedikit juga membuat ia lalai beribadah kepada Tuhan, justru semakin menambah ketaatannya. Iblis senantiasa berusaha menggoda Nabi Ayub, dengan jalan mengadukannya (memprovokasi) kepada Tuhan, bahwa ketaatan Nabi Ayub itu tidaklah suci-ikhlas, tapi hanya karena hendak mempertahankan nikmat yang diperolehnya. Kalau nikmat itu dicabut, kata iblis, maka ia akan menjadi seorang yang ingkar dan fasik. Walaupun Tuhan Maha Mengetahui tentang Segala Sesuatu, tapi Allah sengaja memperkenankan permintaan iblis, untuk dijadikan

\footnotetext{
${ }^{28}$ Mubarok, Solusi Krisis, 74.

${ }^{29}$ Ibid., 75.
} 
contoh teladan tentang kesabaran Nabi Ayub. ${ }^{30}$

\section{Keutamaan Sabar}

Seorang mukmin yang sabar tidak akan berkeluh kesah dalam menghadapi segala kesusahan yang menimpanya, serta tidak akan menjadi lemah atau jatuh gara-gara musibah dan bencana yang menderanya. Allah Swt. telah mewasiatkan kesabaran kepada hambanya serta mengajari bahwa apapun yang menimpanya pada kehidupan dunia hanyalah merupakan cobaan dari-Nya supaya diketahui orang-orang yang bersabar. Kesabaran mengajari manusia ketekunan dalam bekerja serta mengerahkan kemampuan untuk merealisasikan tujuan-tujuan amaliah dan ilmiahnya. Sesungguhnya sebagian besar tujuan hidup manusia, baik di bidang kehidupan praksis misalnya sosial, ekonomi, dan politik maupun di bidang penelitian ilmiah, membutuhkan banyak waktu dan banyak kesungguhan. Oleh sebab itu, ketekunan dalam mencurahkan kesungguhan serta kesabaran dalam menghadapi kesulitan pekerjaan dan penelitian merupakan karakter penting untuk meraih kesuksesan dan mewujudkan tujuan-tujuan luhur. ${ }^{31}$

Sifat sabar dalam Islam menempati posisi yang istimewa. Al-Qur'an mengaitkan sifat sabar dengan bermacam-macam sifat mulia lainnya. Antara lain dikaitkan dengan keyakinan (Q.S. as-Sajdah [32]: 24), syukur (Q.S. Ibrahim [14]: 5), tawakkal (Q.S. an-Nahl [16]: 41-42) dan taqwa (Q.S. Ali 'Imran [3]: 15-17). Mengaitkan satu sifat dengan banyak sifat mulia lainnya menunjukkan betapa istimewanya sifat sabar. Karena sabar merupakan sifat mulia yang istimewa, tentu dengan sendirinya orangorang yang sabar juga menempati posisi yang istimewa. Misalnya, dalam menyebutkan orang-orang beriman yang akan mendapat surga dan keridhaan Allah Swt., orang-orang yang sabar ditempatkan dalam urutan pertama sebelum yang lain-lainnya.

Perhatikan firman Allah berikut ini:

\footnotetext{
${ }^{30}$ Nasution, Islam Ditinjau dari Berbagai Aspeknya, 199

${ }^{31}$ Najati, Psikologi dalam al-Qur'an, 467, 471.
} 


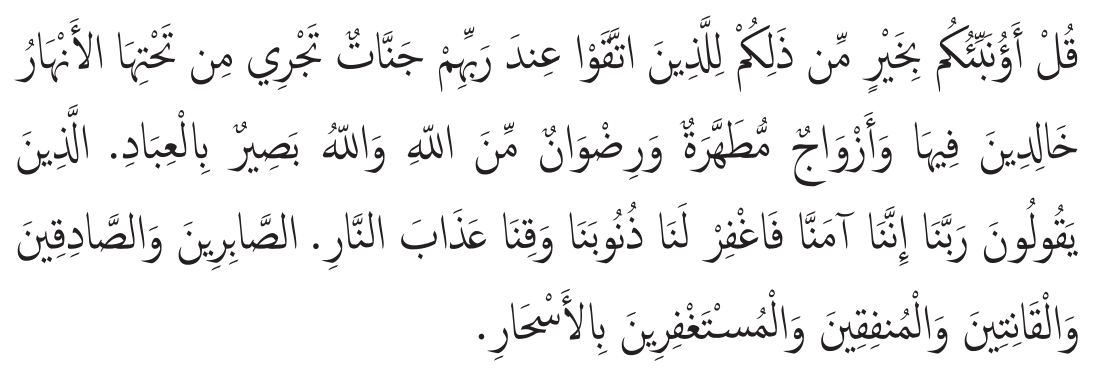

Katakanlah "Ingin aku kabarkan kepadamu apa yang lebih baik dari yang demikian itu". Untuk orang-orang yang bertaqwa, pada sisi Tuhan mereka ada surga yang mengalir di bawahnya sungai-sungai; mereka kekal di dalamnya. Dan ada pula pasanganpasangan yang disucikan serta keridhaan Allah. Dan Allah Maha Melihat akan hamba-hamba-Nya. Yaitu orang-orang yang berdo'a: "Ya Tuhan Kami, sesungguhnya kami telah beriman, maka ampunilah segala dosa kami dan peliharalah kami dari siksa neraka. Yaitu orang-orang yang sahar, yang benar, yang tetap ta'at, yang menafkahkan hartanya (di jalan Allah), dan yang memohon ampun di waktu sahur. (Q.S. Ali 'Imran [3]: 15-17)

Di samping itu, setelah menyebutkan dua belas sifat hamba-hamba yang akan mendapatkan kasih sayang dari Allah SWT (dalam Surat Al-Furqan 25: 63-74), Allah SWT menyatakan bahwa mereka akan mendapatkan balasan surga karena kesabaran mereka. Artinya untuk dapat memenuhi dua belas sifat-sifat tersebut diperlukan kesabaran.

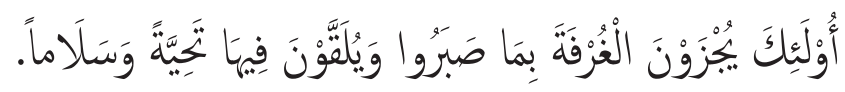

Mereka itulah orang yang dibalasi dengan martabat yang tinggi (dalam surga) karena kesabaran mereka dan mereka disambut dengan penghormatan dan ucapan selamat di dalamnya. (Q.S. alFurqan [25]: 75)

Di samping segala keistimewaan itu, sifat sabar memang sangat dibutuhkan sekali untuk mencapai kesuksesan dunia dan Akhirat. Seorang mahasiswa tidak akan dapat berhasil mencapai gelar kesarjanaan tanpa sifat sabar dalam belajar. Seorang peneliti tidak akan dapat menemukan 
penemuanpenemuan ilmiah tanpa ada sifat sabar dalam penelitiannya. Demikianlah seterusnya dalam seluruh aspek kehidupan. Lawan dari sifat sabar adalah al-jaza'u yang berarti gelisah, sedih, keluh kesah, cemas dan putus asa, sebagaimana dalam firman Allah SWT:

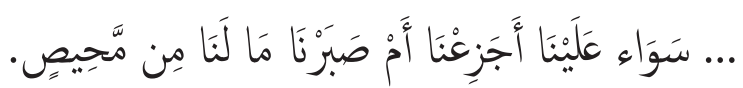

Sama saja bagi kita, mengeluh ataukah bersabar. Sekali-kali kita tidak mempunyai tempat untuk melarikan diri. (Q.S. Ibrahim [14]: 21)

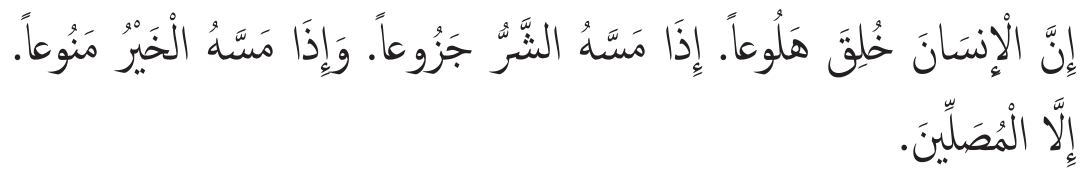

Sesungguhnya manusia diciptakan bersifat keluh kesah lagi kikir. Apabila ia ditimpa kesusahan ia berkeluh kesah. Dan apabila ia mendapat kebaikan ia amat kikir. Kecuali orang-orang yang mengerjakan shalat. (Q.S. al-Ma'arij [70]: 19-22)

Ketidaksabaran dengan segala bentuknya adalah sifat yang tercela. Orang yang dihinggapi sifat ini, bila menghadapi hambatan dan mengalami kegagalan akan mudah goyah, berputus asa dan mundur dari medan perjuangan. Sebaliknya, apabila mendapatkan keberhasilan juga cepat lupa diri. Menurut ayat di atas, kalau ditimpa kesusahan dia berkeluh kesah, kalau mendapat kebaikan ia amat kikir. Maka, sudah semestinya setiap Muslim dan Muslimah menjauhi sifat yang tercela ini.

\section{Kesehatan Mental}

Sebagai makhluk yang memiliki kesadaran, manusia menyadari adanya problem yang mengganggu mentalnya, oleh karena itu sejarah manusia juga mencatat adanya upaya mengatasi problema tersebut. Upaya-upaya tersebut ada yang bersifat mistik yang irasional, ada juga yang bersifat rasional, konsepsional dan ilmiah. ${ }^{32}$ Pada masyarakat Barat

\footnotetext{
${ }^{32}$ Mubarok, Solusi Krisis, 13.
} 
modern atau masyarakat yang mengikuti peradaban Barat yang sekular, solusi yang ditawarkan untuk mengatasi problem mental itu dilakukan dengan menggunakan pendekatan psikologi, dalam hal ini kesehatan mental. Sedangkan pada masyarakat Islam, karena mereka (kaum Muslimin) pada awal sejarahnya telah mengalami problem psikologis seperti yang dialami oleh masyarakat Barat, maka solusi yang ditawarkan lebih bersifat religius spiritual, yakni tasawuf atau akhlak. Keduanya menawarkan solusi bahwa manusia itu akan memperoleh kebahagiaan pada zaman apapun, jika hidupnya bermakna. ${ }^{33}$

Islam menetapkan tujuan pokok kehadirannya untuk memelihara agama, mental spiritual, akal, jasmani, harta, dan keturunan. Setidaknya tiga dari yang disebut di atas berkaitan dengan kesehatan. Tidak heran jika ditemukan bahwa Islam sangat kaya dengan tuntunan kesehatan. ${ }^{34}$ Namun, demikian para ahli belum ada kesepakatan terhadap batasan atau definisi kesehatan mental. Hal itu antara lain karena adanya berbagai sudut pandang dan sistem pendekatan yang berbeda. Dengan tiadanya kesatuan pendapat dan pandangan tersebut, maka menimbulkan adanya perbedaan konsep kesehatan mental. Lebih jauh lagi mengakibatkan terjadinya perbedaan implementasi dalam mencapai dan mengusahakan mental yang sehat. Perbedaan itu wajar dan tidak perlu merisaukan, karena sisi lain adanya perbedaan itu justru memperkaya khasanah dan memperluas pandangan orang mengenai apa dan bagaimana kesehatan mental. ${ }^{35}$ Sejalan dengan keterangan di atas, maka di bawah ini dikemukakan beberapa rumusan kesehatan mental, antara lain:

Pertama, menurut Daradjat, dalam pidato pengukuhannya sebagai guru besar IAIN Syarif Hidayatullah Jakarta (1984) mengemukakan lima rumusan kesehatan mental yang lazim dianut para ahli. Kelima rumusan itu disusun mulai dari rumusan-rumusan yang khusus sampai dengan yang lebih umum, sehingga dari urutan itu tergambar bahwa

${ }^{33}$ Ibid., 14.

${ }^{34}$ Shihab, Wawasan al-Qur'an, 181.

35 Thohari Musnamar, Dasar-Dasar Konseptual Bimbingan dan Konseling Islami (Yogyakarta: UII Press, 1992), xiii. 
rumusan yang terakhir seakan-akan mencakup rumusan-rumusan sebelumnya. Kedua, menurut M. Buchori, kesehatan mental adalah ilmu yang meliputi sistem tentang prinsip-prinsip, peraturan-peraturan serta prosedur-prosedur untuk mempertinggi kesehatan ruhani. Orang yang sehat mentalnya ialah orang yang dalam ruhani atau dalam hatinya selalu merasa tenang, aman, dan tenteram. Jalaluddin dengan mengutip H.C. Witherington menambahkan, permasalahan kesehatan mental menyangkut pengetahuan serta prinsip-prinsip yang terdapat lapangan psikologi, kedokteran, psikiatri, biologi, sosiologi, dan agama. ${ }^{36}$ Ketiga, Kartini Kartono dan Jenny Andari mengetengahkan rumusan bahwa mental hygiene atau ilmu kesehatan mental adalah ilmu yang mempelajari masalah kesehatan mental/jiwa, bertujuan mencegah timbulnya gangguan/penyakit mental dan gangguan emosi, dan berusaha mengurangi atau menyembuhkan penyakit mental, serta memajukan kesehatan mental rakyat. Dengan demikian, mental hygiene mempunyai tema sentral, yaitu bagaimana cara orang memecahkan segenap keruwetan batin manusia yang ditimbulkan oleh macam-macam kesulitan hidup, serta berusaha mendapatkan kebersihan mental, dalam pengertian tidak terganggu oleh macam-macam ketegangan, kekalutan dan konflik terbuka serta konflik batin. ${ }^{37}$

Kesehatan mental seseorang berhubungan dengan kemampuan menyesuaikan diri dengan keadaan yang dihadapi. Setiap manusia memiliki keinginan-keinginan tertentu, dan di antara mereka ada yang berhasil memperolehnya tanpa harus bekerja keras, ada yang memperolehnya setelah berjuang mati-matian, dan ada yang tidak berhasil menggapainya meskipun telah bekerja keras dan bersabar untuk menggapainya. Dari berbagai definisi tersebut, maka definisi dari Daradjat khususnya yang kelima lebih mencakup keseluruhan unsur-unsur kesehatan mental. Di samping itu, definisi tersebut memasukkan unsur agama yang sangat penting dan harus diupayakan penerapannya dalam kehidupan sejalan

\footnotetext{
${ }^{36}$ Jalaludin, Psikologi Agama (Jakarta: Raja Grafindo Persada, 2004), 154.

${ }^{37}$ Kartini Kartono dan Jeny Andari, Hygine Mental dan Kesehatan Mental dalam Islam (Bandung: CV. Mandar Maju, 1989), 4.
} 
dengan penerapan prinsip-prinsip kesehatan mental dan pengembangan hubungan baik dengan sesama manusia. Dengan demikian, dapat disimpulkan bahwa kesehatan mental adalah terhindarnya seseorang dari gejala-gejala gangguan dan penyakit mental, dapat menyesuaikan diri, dapat memanfaatkan segala potensi dan bakat semaksimal mungkin, dan membawa kepada kebahagiaan bersama serta tercapainya keharmonisan dalam hidup.

Lebih lanjut, ada batasan yang luas tentang kesehatan mental. Pengertian kesehatan mental tidak hanya terbatas pada terhindarnya seseorang dari gangguan dan penyakit kejiwaan, akan tetapi orang yang bersangkutan juga memiliki karakter utama sebagai berikut: ${ }^{38}$

a. Sikap kepribadian yang baik terhadap diri sendiri, dalam arti ia dapat mengenal dirinya dengan baik.

b. Pertumbuhan, perkembangan, dan perwujudan diri yang baik.

c. Integrasi diri yang meliputi keseimbangan mental, kesatuan pandangan, dan sabar terhadap tekanan-tekanan yang terjadi.

d. Otonomi diri yang mencakup unsur-unsur pengatur kelakuan diri atau kelakuan-kelakuan bebas.

e. Persepsi mengenai realitas, bebas dari penyimpangan kebutuhan, serta memiliki empati dan kepekaan sosial.

f. Kemampuan untuk menguasai lingkungan dan berintegrasi dengannya secara baik.

Jasmani yang sehat ditandai oleh ciri-ciri memiliki energi, daya tahan atau stamina yang tinggi, kuat bekerja, serta badan selalu sehat dan nyaman. Adapun mentalitas yang sehat memiliki gejala: posisi pribadinya harmonis dan seimbang, baik ke dalam, terhadap diri sendiri, maupun keluar, terhadap lingkungan sosialnya. Oleh karena itu, ciri-ciri khas pribadi yang bermental sehat, antara lain berikut ini. Ada koordinasi dari segenap usaha dan potensinya sehingga mudah mengadakan adaptasi terhadap tuntutan lingkungan, standar, dan norma sosial, serta perubahan-perubahan sosial yang serba cepat.

\footnotetext{
${ }^{38}$ Ibid., 8
} 
a. Memiliki integrasi dan regulasi terhadap struktur kepribadian sendiri sehingga mampu memberikan partisipasi aktif kepada masyarakat.

b. Senantiasa giat melaksanakan proses realisasi diri (yaitu mengembangkan secara riil segenap bakat dan potensi), memiliki tujuan hidup, dan selalu mengarah pada transendensi diri, berusaha untuk melebihi kondisinya yang sekarang.

c. Bergairah, sehat lahir dan batin, tenang dan harmonis kepribadiannya, efisien dalam setiap tindakannya, serta mampu menghayati kenikmatan dan kepuasan dalam pemenuhan kebutuhannya. ${ }^{39}$

Di pihak lain, Organisasi Kesehatan Sedunia (WHO, 1959) memberikan kriteria mental yang sehat, yaitu sebagai berikut:

a. Dapat menyesuaikan diri secara konstruktif pada kenyataan meskipun kenyataan itu buruk baginya.

b. Memperoleh kepuasan dari hasil jerih payah usahanya,

c. Merasa lebih puas memberi daripada menerima.

d. Secara relatif bebas dari rasa tegang dan cemas.

e. Berhubungan dengan orang lain secara tolong-menolong dan saling memuaskan.

f. Menerima kekecewaan untuk dipakainya sebagai pelajaran di kemudian hari.

g. Menjuruskan rasa permusuhan pada penyelesaian yang kreatif dan konstruktif.

h. Mempunyai rasa kasih sayang yang besar. ${ }^{40}$

Sementara itu, Rosihan Anwar dan M. Solihin memberikan tolok ukur bagi orang yang sehat mentalnya, yaitu mampu merasakan kebahagiaan dalam hidup. Orang-orang inilah yang dapat merasakan bahwa

\footnotetext{
${ }^{39}$ Ibid., 82.

${ }^{40}$ Dadang Hawari, Al-Qur'an: Ilmu Kedokteran Jiwa dan Kesehatan Jiwa (Yogyakarta: PT. Dana Bhakti Prima Yasa, 1996), 12-13.
} 
dirinya berguna, berharga, dan mampu menggunakan segala potensi dan bakatnya semaksimal mungkin dengan cara membawa dirinya dan orang lain pada kebahagiaan. Di samping itu, ia mampu menyesuaikan diri dalam arti yang luas sehingga terhindar dari kegelisahan dan gangguan jiwa, dan moralnya pun selalu terpelihara. ${ }^{41}$ Dari pengertian tersebut, dapat diketahui bahwasanya tolok ukur orang yang benar-benar sehat mentalnya adalah orang yang beriman, dan bertakwa kepada Tuhan Yang Maha Esa, serta berusaha secara sadar merealisasikan nilai-nilai agama sehingga kehidupannya itu dijalaninya sesuai dengan tuntutan agama.

\section{Kesehatan Mental dalam Islam}

Menurut Moeljono Notosoedirjo, guru besar psikiatri dan kesehatan mental Fakultas Kedokteran dan Program Pascasarjana Universitas Airlangga Surabaya, untuk menetapkan suatu keadaan psikologis berada dalam keadaan sehat tidaklah mudah. Namun demikian, para ahli kesehatan mental telah membuat kriteria-kriteria atau kondisi optimum seseorang dapat dikatakan berada dalam kondisi yang sehat. Kondisi optimum ini dapat dijadikan sebagai acuan dan arah yang dapat dituju dalam melakukan pemeliharaan dan peningkatan kesehatan mental serta pencegahannya. ${ }^{42}$

Di kalangan ahli kesehatan mental, istilah yang digunakan untuk menyebut kesehatan mental berbeda-beda, kriteria yang dibuat pun tidak sama secara tekstual, meskipun memiliki maksud yang sama. Dapat disebut di sini, Maslow menyebut kondisi optimum itu dengan self-actualization, Rogers menyebutnya dengan fully functioning, Allport memberi nama dengan mature personality, dan banyak yang menyebut dengan mental health. ${ }^{43}$ Semua pandapat pada dasarnya sama, jadi tidak perlu diperdebatkan, sebab berada dalam kerangka teorinya masing-masing. Pada bagian-berikut akan diuraikan berbagai pandangan tentang kriteria

\footnotetext{
${ }^{41}$ Ibid., 15.

42 Moeljono Notosoedirjo, Kesehatan Mental Konsep \& Penerapan (Malang: Penerbit Universitas Muhammadiyah Malang, 1999), 25.

${ }^{43}$ Ibid., 24-31.
} 
kesehatan mental itu satu persatu, dengan maksud dapat memberikan gambaran yang lebih luas tentang kondisi mental yang sehat.

Berangkat dari keterangan tersebut, Kartini Kartono berpendapat ada tiga prinsip pokok untuk mendapatkan kesehatan mental, yaitu:

a. Pemenuhan Kebutuhan Pokok. Setiap individu selalu memiliki dorongan-dorongan dan kebutuhan-kebutuhan pokok yang bersifat organis (fisik dan psikis) dan yang bersifat sosial. Kebutuhan-kebutuhan dan dorongan-dorongan itu menuntut pemuasan. Timbullah ketegangan-ketegangan dalam usaha pencapaiannya. Ketegangan cenderung menurun jika kebutuhankebutuhan terpenuhi, dan cenderung naik/makin banyak, jika mengalami frustasi atau hambatan-hambatan.

b. Kepuasan. Setiap orang menginginkan kepuasan, baik yang bersifat jasmaniah maupun yang bersifat psikis. Dia ingin merasa kenyang, aman terlindung, ingin puas dalam hubungan seksnya, ingin mendapat simpati dan diakui harkatnya. Pendeknya, ingin puas di segala bidang, lalu timbul sense of importancy dan sense of mastery (kesadaran nilai dirinya dan kesadaran penguasaan) yang memberi rasa senang, puas dan bahagia.

c. Posisi dan Status Sosial. Setiap individu selalu berusaha mencari posisi sosial dan status sosial dalam lingkungannya. Tiap manusia membutuhkan cinta kasih dan simpati. Sebab cinta kasih dan simpati menumbuhkan rasa diri aman (assurance), keberanian dan harapan-harapan di masa mendatang. Orang lalu menjadi optimis dan bergairah. Karenanya individu-individu yang mengalami gangguan mental, biasanya merasa dirinya tidak aman. Mereka senantiasa dikejar-kejar dan selalu dalam kondisi ketakutan. Dia tidak mempunyai kepercayaan pada diri sendiri dan hari esok, jiwanya senantiasa bimbang dan tidak imbang. ${ }^{44}$

Dalam Islam pengembangan kesehatan mental terintegrasi dalam

\footnotetext{
${ }^{44}$ Kartono \& Andari, Hygine Mental, 29-30.
} 
pengembangan pribadi pada umumnya, dalam artian kondisi kejiwaan yang sehat merupakan hasil sampingan dari kondisi pribadi yang matang secara emosional, intelektual, dan sosial, serta terutama matang pula ketuhanan dan ketakwaan kepada Tuhan Yang Maha Esa. Dengan demikian dalam Islam dinyatakan betapa pentingnya pengembangan pribadi-pribadi meraih kualitas "insan paripurna", yang otaknya sarat dengan ilmu yang bermanfaat, bersemayam dalam kalbunya iman dan taqwa kepada Tuhan. Sikap dan tingkah lakunya benar-benar merefleksikan nilai-nilai keislaman yang mantap dan teguh. Otaknya terpuji dan bimbingannya terhadap masyarakat membuahkan ketuhanan, rasa kesatuan, kemandirian, semangat kerja tinggi, kedamaian dan kasih sayang. Kesan demikian pasti jiwanya pun sehat. Suatu tipe manusia ideal dengan kualitas-kualitasnya mungkin sulit dicapai. Tetapi dapat dihampiri melalui berbagai upaya yang dilakukan secara sadar, aktif dan terencana sesuai dengan prinsip yang terungkap dalam firman Allah Swt. (Q.S. ar-Rad [13]: 11). ${ }^{45}$

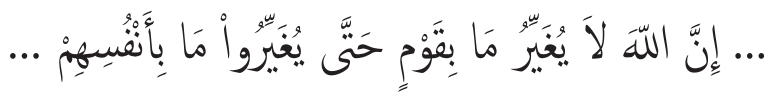

Sesungguhnya Allah tidak mengubah suatu kaum sehingga mereka mengubah keadaan yang ada pada diri mereka sendiri.

Ayat ini menunjukkan bahwa Islam mengakui kebebasan berkehendak dan menghargai pilihan pribadi untuk menentukan apa yang terbaik baginya. Dalam hal ini manusia diberi kebebasan untuk secara sadar aktif melakukan lebih dahulu segala upaya untuk meningkatkan diri dan merubah nasib sendiri dan baru setelah itu hidayah Allah akan tercurah padanya. Sudah tentu upaya-upaya dapat meraih hidayah Allah Swt. itu harus sesuai dan berdasarkan al-Qur'an dan Hadis. Selain itu, dalam Islam kebebasan bukan merupakan kebebasan tak terbatas, karena niat, tujuan, dan cara-caranya harus selalu sesuai dengan nilai-nilai agama dan norma-norma yang berlaku. Melihat uraian di atas bahwa

\footnotetext{
${ }^{45}$ Hanna Djumhana Bastaman, Integrasi Psikologi dengan Islam: Menuju Psikologi Islami (Yogyakarta: Yayasan Insan Kamil \& Pustaka Pelajar, 2001), 150.
} 
kesehatan mental dalam perspektif Islam sesuai dengan kriteria mental yang sehat perspektif Organisasi Kesehatan Sedunia (WHO, 1959) yang memberikan kriteria mental yang sehat, yaitu sebagai berikut.

1. Dapat menyesuaikan diri secara konstruktif pada kenyataan meskipun kenyataan itu buruk baginya.

2. Memperoleh kepuasan dari hasil jerih payah usahanya.

3. Merasa lebih puas memberi daripada menerima.

4. Secara relatif bebas dari rasa tegang dan cemas.

5. Berhubungan dengan orang lain secara tolong-menolong dan saling memuaskan.

6. Menerima kekecewaan untuk dipakainya sebagai pelajaran di kemudian hari.

Meskipun pendapat tokoh-tokoh di atas sesuai dengan kriteria WHO, tetapi ada perbedaan yang mendasar yaitu aspek religius tidak menjadi perhatian WHO. Hal ini terbukti dari unsur-unsur yang dikembangkan WHO sama sekali tidak menyentuh masalah agama. Hal itu dapat dimengerti karena kriteria WHO ditujukan untuk semua agama sehingga komponen yang dikembangkan WHO bersifat universal dan tidak ditujukan pada satu agama. Sedangkan tokoh-tokoh Islam yang menyoroti kesehatan mental perspektif Islam telah mengulas dan menyentuh persoalan tauhid atau keimanan bahkan akhlak. Hal ini sebagaimana dikemukakan Bastaman bahwa kesehatan mental tidak akan terbentuk jika hanya mengandalkan logika dan nalar semata, sentuhan agama menjadi bagian mutlak untuk mengembangkan mental yang sehat. ${ }^{46}$

Selanjutnya kesehatan mental yang menjadi acuan banyak orang akan gagal, jika lepas dari aspek agama karena agama mengandung unsur spiritual yang besar. Perbedaan lainnya antara WHO dengan pandangan tokoh Muslim, yaitu bahwa WHO tidak memuat unsur akhlak al-karimah (akhlak yang mulia), sedangkan tokoh Muslim, seperti Jalaluddin, menganggap utama masalah akhlak karena tanpa akhlak al-karimah mustahil

\footnotetext{
${ }^{46}$ Ibid., 152.
} 
bisa menghasilkan manusia yang sehat mentalnya. ${ }^{47}$

\section{Materi dan Metode Bimbingan Konseling Islam}

Pengertian harfiah bimbingan adalah menunjukkan, memberi jalan, atau menuntun orang lain ke arah tujuan yang bermanfaat bagi hidupnya di masa kini dan masa mendatang. Istilah bimbingan merupakan terjemahan dari kata bahasa Inggris guidance yang berasal dari kata kerja to guide yang berarti menunjukkan. Secara etimologis, istilah konseling berasal dari bahasa Latin, yaitu consilium yang berarti dengan atau bersama yang dirangkai dengan menerima atau memahami. Sedangkan dalam bahasa Anglo-Saxon, istilah konseling berasal dari sellan yang berarti menyerahkan atau menyampaikan. ${ }^{48}$ Menurut Walgito, bimbingan adalah bantuan atau pertolongan yang diberikan kepada individu atau sekumpulan individu dalam menghadapi atau mengatasi kesulitan-kesulitan di dalam kehidupannya agar individu atau sekumpulan individu itu dapat mencapai kesejahteraan hidupnya. ${ }^{49}$ Dengan memperhatikan rumusan tersebut, maka dapat disimpulkan bahwa bimbingan dan konseling merupakan pemberian bantuan yang diberikan kepada individu guna mengatasi berbagai kesukaran di dalam kehidupannya agar individu itu dapat mencapai kesejahteraan hidupnya.

Dalam tulisan ini, bimbingan dan konseling yang di maksud adalah yang Islami, maka ada baiknya kata Islam diberi arti lebih dahulu. Secara etimologi, Islam berasal dari bahasa Arab, salima yang berarti selamat sentosa. Dari asal kata itu dibentuk kata aslama yang artinya memeliharakan dalam keadaan selamat sentosa, dan berarti juga menyerahkan diri, tunduk, patuh dan taat. Kata aslama itulah menjadi pokok kata Islam mengandung segala arti yang terkandung dalam arti pokoknya, sebab itu

\footnotetext{
${ }^{47}$ Kartono dan Andari, Hygine Mental, 13.

${ }^{48}$ Erman Amti Prayitno, Dasar-Dasar Bimbingan dan Konseling (Jakarta: PT Rineka Cipta, 2004), 99.

${ }^{49}$ Bimo Walgito, Bimbingan dan Penyuluhan di Sekolah (Yogyakarta: Andi Offset, 1989), 4.
} 
orang yang melakukan aslama atau masuk Islam dinamakan Muslim..$^{50}$ Secara terminologis, sebagaimana dirumuskan oleh Harun Nasution, Islam adalah agama yang ajaran-ajarannya diwahyukan Tuhan kepada masyarakat manusia melalui Nabi Muhammad Saw. sebagai Rasulullah. ${ }^{51}$

Bertitik tolak dari uraian tersebut, maka yang dimaksud bimbingan Islami adalah proses pemberian bantuan terhadap individu agar mampu hidup selaras dengan ketentuan dan petunjuk Allah sehingga dapat mencapai kebahagiaan hidup di dunia dan di akhirat. Sedangkan konseling Islam adalah proses pemberian bantuan terhadap individu agar menyadari kembali akan eksistensinya sebagai makhluk Allah yang seharusnya hidup selaras dengan ketentuan dan petunjuk Allah sehingga dapat mencapai kebahagiaan di dunia dan di akhirat. ${ }^{52}$

Bimbingan dan konseling Islami berkaitan dengan masalah yang dihadapi individu, yang mungkin dihadapi individu, atau yang sudah dialami individu. Masalah itu sendiri, dapat muncul dari berbagai faktor atau bidang kehidupan. Jika dirinci, dengan pengelompokan, masalahmasalah itu dapat menyangkut bidang-bidang:

1. Pernikahan dan Keluarga

Anak dilahirkan dan dibesarkan (umumnya) di lingkungan keluarga, entah itu keluarga intinya (ayah dan ibunya sendiri), entah itu keluarga lain, atau keluarga besar (sanak keluarga). Keluarga lazimnya diikat oleh tali pernikahan. Pernikahan dan ikatan keluarga di satu sisi merupakan manfaat, di sisi lain dapat mengandung mudarat atau menimbulkan kekecewaan-kekecewaan. Dalam pada itu pernikahan dan kekeluargaan sudah barang tentu tidak terlepas dari lingkungannya (sosial maupun fisik) yang mau tidak mau mempengaruhi kehidupan keluarga dan keadaan pernikahan. Karena itulah maka bimbingan dan konseling Islami kerapkali amat diperlukan untuk menangani

\footnotetext{
${ }^{50}$ Ibid., 6.

${ }^{51}$ Nasution, Islam Ditinjau dari Berbagai Aspek, 24.

${ }^{52}$ Musnamar, Dasar-Dasar Konseptual Bimbingan, 5.
} 